\title{
The timing of spring migration in trans-Saharan migrants: a comparison between Ottenby, Sweden and Capri, Italy
}

\author{
Vårflyttningens tidsmönster hos tropikflyttare: en jämförelse mellan Ottenby, \\ Sverige och Capri, Italien
}

NICLAS JONZÉN, DARIO PIACENTINI, ARNE ANDERSSON, ALESSANDRO MONTEMAGGIORI,
MARTIN STERVANDER, DIEGO RUBOLINI, JONAS WALDENSTRÖM \& FERNANDO SPINA Abstract

Some migratory birds have advanced their spring arrival to Northern Europe, possibly by increasing the speed of migration through Europe in response to increased temperature en route. In this paper we compare the phenology of spring arrival of seven trans-Saharan migrants along their migration route and test for patterns indicating that migration speed varied over the season using long-term data collected on the Italian island of Capri and at Ottenby Bird Observatory, Sweden. There was a linear relationship between median arrival dates on Capri and at Ottenby. The slope was not significantly different from one. On average, the seven species arrived 15 days later at Ottenby compared to Capri. There was a (non-significant) negative relationship between the species-specific arrival dates at Capri and the differences in median arrival dates between Capri and Ottenby, possibly indicating a tendency towards faster migration through Europe later in the season. To what extent different species are able to speed up their migra- tion to benefit from the advancement of spring events is unknown.

Niclas Jonzén, Department of Theoretical Ecology, Ecology Building, Lund University, SE-223 62 Lund, Sweden.Email: niclas.jonzen@teorekol.lu.se Dario Piacentini, Alessandro Montemaggiori and Fernando Spina, Istituto Nazionale per la Fauna Selvatica, via Ca' Fornacetta 9, I-40064 Ozzano Emilia (BO), Italy

Arne Andersson and Martin Stervander, Ottenby Bird Observatory, P. O. Box 1500, SE-380 65 Degerhamn, Sweden

Diego Rubolini, Dipartimento di Biologia Animale, Università degli Studi di Pavia, piazza Botta 9, I-27100 Pavia, Italy

Jonas Waldenström, Department of Animal Ecology, Ecology Building, Lund University, SE-223 62 Lund, Sweden

\section{Received 17 July 2005, Accepted 12 Jan 2006, Editor: D. Hasselquist}

\section{Introduction}

Over the past decades many organisms have advanced the timing of spring events, most likely in response to recent climate change (e.g. Stenseth et al. 2002, Walther et al. 2002, Parmesan \& Yohe 2003). For instance, recent empirical work has demonstrated changing phenology patterns in the flowering of plant species (Fitter \& Fitter 2002), in the emergence from pupae in insects (Roy \& Sparks 2000), and in earlier breeding by amphibians (Beebee 1995) and birds (Crick et al. 1997). Most ornithological studies demonstrating temporal trends towards earlier spring arrival or egg-laying dates have been carried out in the temperate region of Europe and North America (reviewed by Lehikoinen et al. 2004, Dunn 2004), whereas only a few publications cover the Mediterranean region or Africa (e.g. Peñuelas et al. 2002, Sanz et al. 2003, Gordo et al. 2005). Thus, at present our understanding of these patterns in migrant birds is somewhat biased towards the situation close to the breeding areas, which makes it difficult to identify to what extent arrival patterns in Northern Europe are caused by processes in Africa or along the migration route through Europe.

One hypothesis to explain how tropical migrants can advance their spring arrival to Northern Europe is that the migration speed through Europe has increased, as suggested by e.g. Hüppop \& Hüppop (2003). A more rapid spring migration in response to increased temperature en route has recently been demonstrated in the Pied Flycatcher Ficedula hypoleuca (Both et al. 2005). However, the ability to speed up migration may be affected 
by the "normal" speed of migration, which in turn may vary across species.

In this paper, we compare the phenology of spring arrival of seven trans-Saharan migrants along their migration route by analysing long-term data collected on the island of Capri, Italy, and at Ottenby Bird Observatory, Sweden. By analysing the relationship between arrival dates at Ottenby and on Capri we tested for patterns indicating whether migration speed varied over season. Late migrating species may be more time constrained than early migrating species, and they may therefore migrate faster.

\section{Material and methods}

\section{Study sites}

The island of Capri is situated c. $5 \mathrm{~km}$ off mainland Italy, in the bay of Naples, with the trapping site $\left(40^{\circ} 33^{\prime} \mathrm{N}, 14^{\circ} 15^{\prime} \mathrm{E}\right)$ located about $400 \mathrm{~m}$ above sea level (Pettersson et al. 1990, Hjort 2006). In spring, many migrating birds stop to rest, at least for a short time (Holmgren \& Engström 2006), on this island after their passage over the Mediterranean Sea. The trapping area on Capri lies mainly within the perimeter of the walls of the old castle Castello Barbarossa and comprises c. 2 ha of macchia vegetation typical for this region of the Mediterranean. However, the plant species and especially the structural composition of the vegetation has changed over the study period, most dramatically by fires (the latest occurred in 1989), which killed the larger pine trees and favoured lower bush vegetation. This could potentially have had an effect on the species composition of the birds trapped, considering that different species have different habitat preferences and the trapping efficiencies of the nets may have changed.

On Capri data have been collected during 45 springs from 1956 to 2004 (no trapping in the period 1982-1985), with the coverage varying from 13 to 89 days per season (Table 1). Birds were trapped with mist nets throughout the study, but the number of nets used varied considerably between, and sometimes also within, years. However, we could not take into account variation in trapping effort in this study. The spring trapping season on Capri is included in the Progetto Piccole Isole, run by the Istituto Nazionale per la Fauna Selvatica (Ozzano Emilia, BO) (Spina 2006).

Ottenby Bird Observatory $\left(56^{\circ} 12^{\prime} \mathrm{N}, 16^{\circ} 24^{\prime} \mathrm{E}\right)$ is situated at the southernmost point of Öland, a $137 \mathrm{~km}$ long island c. $10 \mathrm{~km}$ off the coast of southeastern Sweden. The trapping area in the observa- tory garden is 1.2 hectares and contains most of the higher vegetation within the nearest $2 \mathrm{~km}$. It is surrounded by water on three sides and by grazed meadows to the north. Birds have been caught at Ottenby in funnel traps of Helgoland-type since the first year of trapping in 1946, and mist nets have been used since 1959. Since 1980 the numbers of nets and traps, their position and use in spring have been strictly standardised. We considered data for 53 spring seasons from 1952-2004 as reliable for the purpose of this study. Details on the data collection at Ottenby Bird Observatory are given elsewhere, e.g. in Stervander et al. (2005).

\section{Species analysed}

We have compiled data for seven of the most numerously trapped bird species on Capri: Redstart Phoenicurus phoenicurus, Willow Warbler Phylloscopus trochilus, Icterine Warbler Hippolais icterina, Garden Warbler Sylvia borin, Common Whitethroat Sylvia communis, Spotted Flycatcher Muscicapa striata and Pied Flycatcher Ficedula hypoleuca. We have used ringing recoveries from birds ringed on Capri and elsewhere in the Campania region (Naples, Sorrento, Amalfi; Scebba (1993)), and recoveries of birds ringed at Ottenby to sketch putative breeding areas, migration flyways and possible wintering areas of the investigated species. An underlying assumption when comparing arrival times between Capri and Ottenby is that the species trapped belong roughly to the same population.

\section{Statistical analyses}

We estimated the median spring arrival date for each of the seven species. The estimated medians were not dependent on whether we only analysed data from years including ringing activity on both Capri and at Ottenby, and we therefore decided to keep data from all years. Due to the large samples, any effect of variability in ringing activity within and between seasons was effectively smoothened out.

Because there are observation errors in both the Capri and the Ottenby data sets we performed a reduced major axis (RMA) to test whether the relationship between median arrival on Capri and at Ottenby differed from unity. RMA regression minimize the product of the deviations from the regression line across both the $\mathrm{x}$ (Capri) and the $\mathrm{y}$ (Ottenby) variables. 
Table 1. Ringing details and trapping data from Capri. No ringing in 1982-1985. Species: P.p. $=$ Common Redstart Phoenicurus phoenicurus, H.i. = Icterine Warbler Hippolais icterina, S.c. $=$ Common Whitethroat Sylvia communis, S.b. = Garden Warbler Sylvia borin, P.t. = Willow Warbler Phylloscopus trochilus, M.s. $=$ Spotted Flycatcher Muscicapa striata, F.h. = Pied Flycatcher Ficedula hypoleuca.

Fångsuppgifter från ringmärkningen på Capri. Ingen ringmärkning åren 1982-1985. Arter: P.p. = rödstjärt, H.i. = härmsångare, S.c. = törnsångare, S.b. = trädgårdssångare, P.t. = lövsångare, M.s. = grå flugsnappare, F.h = svartvit flugsnappare.

\begin{tabular}{|c|c|c|c|c|c|c|c|c|c|c|}
\hline \multirow[b]{2}{*}{ Year } & \multicolumn{3}{|c|}{ Catch period Fångstperiod } & \multicolumn{7}{|c|}{ Number of birds ringed Antal märkta fäglar } \\
\hline & Start & Stop & Days & P.p. & H.i. & S.c. & S.b. & P.t. & M.s. & F.h. \\
\hline 1956 & May 1 & May 31 & 31 & 25 & 52 & 57 & 77 & 1 & 14 & 16 \\
\hline 1957 & Apr 1 & May 30 & 60 & 164 & 320 & 227 & 445 & 69 & 125 & 88 \\
\hline 1958 & May 1 & Jun 11 & 42 & 177 & 501 & 361 & 1248 & 26 & 339 & 54 \\
\hline 1959 & Apr 26 & Jun 20 & 56 & 199 & 934 & 450 & 1305 & 53 & 664 & 264 \\
\hline 1960 & Apr 15 & May 23 & 39 & 618 & 405 & 661 & 1327 & 235 & 347 & 539 \\
\hline 1961 & Mar 23 & Jun 3 & 73 & 257 & 880 & 563 & 1472 & 89 & 880 & 286 \\
\hline 1962 & Mar 9 & Jun 5 & 89 & 105 & 103 & 524 & 170 & 204 & 429 & 152 \\
\hline 1963 & Mar 24 & May 31 & 69 & 196 & 436 & 330 & 683 & 135 & 578 & 343 \\
\hline 1964 & May 2 & May 27 & 26 & 44 & 608 & 289 & 993 & 33 & 229 & 37 \\
\hline 1965 & Apr 14 & May 27 & 44 & 178 & 420 & 451 & 557 & 378 & 203 & 138 \\
\hline 1966 & Apr 8 & May 27 & 50 & 146 & 427 & 331 & 505 & 108 & 470 & 153 \\
\hline 1967 & Apr 11 & Jun 7 & 58 & 286 & 368 & 240 & 384 & 257 & 194 & 355 \\
\hline 1968 & Apr 9 & May 23 & 45 & 231 & 265 & 401 & 381 & 288 & 346 & 351 \\
\hline 1969 & Apr 1 & May 25 & 55 & 197 & 213 & 408 & 163 & 384 & 294 & 180 \\
\hline 1970 & Apr 7 & May 29 & 53 & 101 & 403 & 593 & 603 & 200 & 382 & 219 \\
\hline 1971 & Mar 24 & Jun 5 & 74 & 140 & 195 & 305 & 223 & 140 & 300 & 144 \\
\hline 1972 & Apr 25 & May 26 & 32 & 194 & 250 & 200 & 387 & 225 & 193 & 140 \\
\hline 1973 & Apr 8 & May 26 & 49 & 89 & 403 & 178 & 266 & 101 & 327 & 114 \\
\hline 1974 & Apr 19 & May 27 & 39 & 75 & 979 & 364 & 910 & 250 & 444 & 89 \\
\hline 1975 & Apr 11 & Jun 2 & 53 & 160 & 374 & 401 & 546 & 124 & 722 & 261 \\
\hline 1976 & Apr 4 & May 28 & 55 & 44 & 457 & 221 & 233 & 74 & 310 & 108 \\
\hline 1977 & Apr 19 & May 23 & 35 & 94 & 149 & 188 & 206 & 70 & 241 & 110 \\
\hline 1978 & Apr 23 & May 30 & 38 & 84 & 358 & 159 & 272 & 81 & 174 & 116 \\
\hline 1979 & Apr 14 & May 23 & 40 & 108 & 624 & 368 & 666 & 282 & 58 & 183 \\
\hline 1980 & May 2 & May 27 & 26 & 37 & 876 & 174 & 423 & 65 & 176 & 46 \\
\hline 1981 & Apr 15 & May 23 & 39 & 88 & 485 & 171 & 180 & 97 & 195 & 174 \\
\hline 1986 & Apr 15 & May 22 & 38 & 122 & 730 & 570 & 1113 & 273 & 474 & 465 \\
\hline 1987 & Apr 11 & May 24 & 44 & 80 & 600 & 623 & 728 & 259 & 134 & 256 \\
\hline 1988 & Apr 16 & May 23 & 38 & 41 & 366 & 185 & 237 & 125 & 280 & 176 \\
\hline 1989 & Mar 18 & May 24 & 68 & 60 & 707 & 614 & 457 & 350 & 258 & 131 \\
\hline 1990 & Apr 5 & May 23 & 49 & 95 & 757 & 902 & 614 & 197 & 572 & 465 \\
\hline 1991 & Apr 2 & May 23 & 52 & 90 & 218 & 221 & 170 & 286 & 126 & 341 \\
\hline 1992 & Apr 5 & May 22 & 48 & 69 & 798 & 419 & 350 & 364 & 538 & 188 \\
\hline 1993 & Apr 1 & May 21 & 51 & 103 & 522 & 1105 & 748 & 433 & 324 & 453 \\
\hline 1994 & Apr 16 & May 15 & 30 & 82 & 314 & 299 & 418 & 226 & 337 & 429 \\
\hline 1995 & Apr 17 & May 15 & 29 & 81 & 236 & 314 & 302 & 241 & 199 & 357 \\
\hline 1996 & Apr 16 & May 15 & 30 & 63 & 71 & 262 & 431 & 245 & 49 & 275 \\
\hline 1997 & Apr 16 & May 15 & 30 & 185 & 334 & 519 & 367 & 422 & 291 & 358 \\
\hline 1998 & Apr 16 & May 15 & 27 & 83 & 178 & 336 & 338 & 396 & 156 & 362 \\
\hline 1999 & Apr 16 & May 15 & 29 & 79 & 451 & 448 & 876 & 321 & 245 & 286 \\
\hline 2000 & May 1 & May 14 & 13 & 15 & 245 & 287 & 355 & 25 & 117 & 107 \\
\hline 2001 & Apr 16 & May 15 & 27 & 119 & 79 & 314 & 284 & 457 & 298 & 497 \\
\hline 2002 & Apr 16 & May 15 & 26 & 133 & 321 & 380 & 266 & 433 & 215 & 297 \\
\hline 2003 & Apr 16 & May 15 & 30 & 74 & 876 & 320 & 487 & 317 & 260 & 566 \\
\hline 2004 & Apr 16 & May 15 & 30 & 105 & 448 & 273 & 282 & 364 & 228 & 450 \\
\hline Total & & & 1959 & 5716 & 19736 & 17006 & 23448 & 9703 & 13735 & 11119 \\
\hline
\end{tabular}



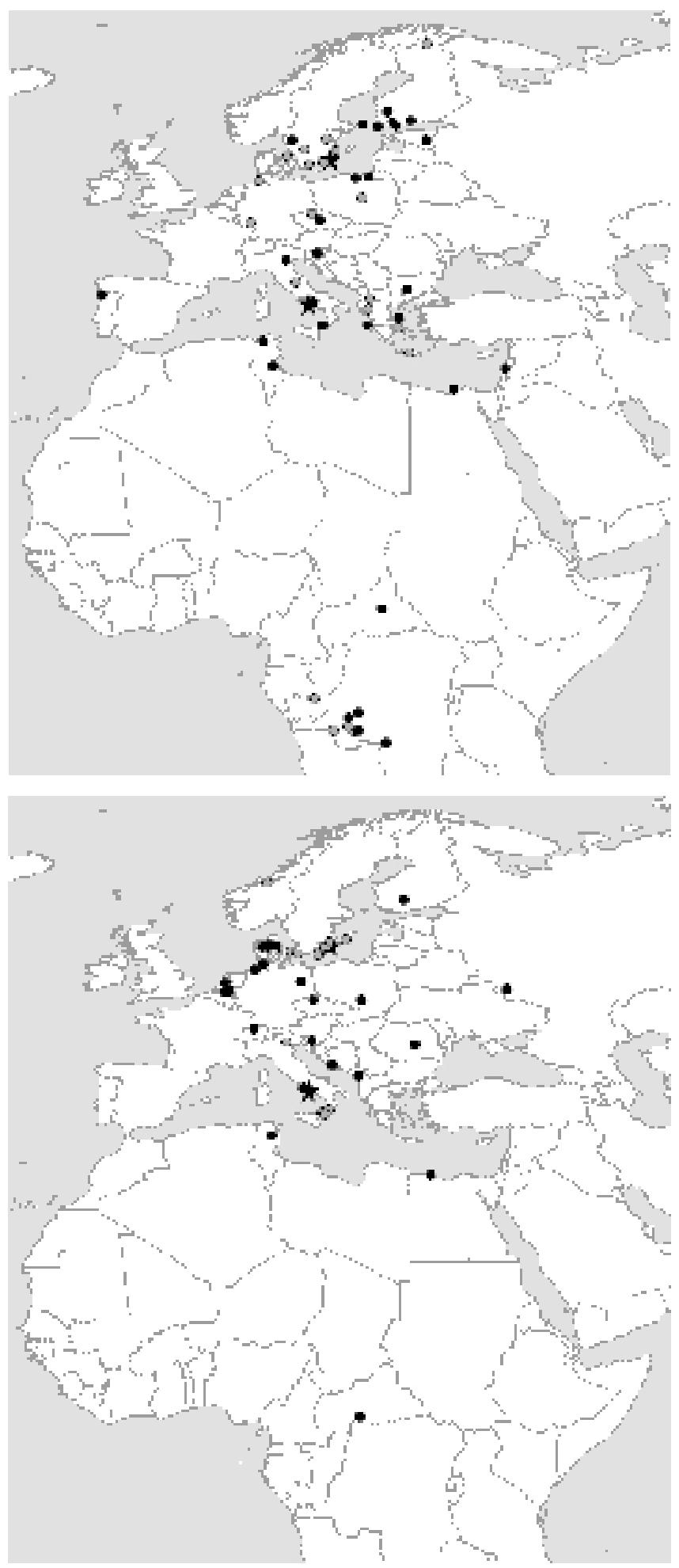

Figure 1. Map showing the recoveries of Spotted Flycatchers Muscicapa striata ringed or controlled at Ottenby (grey circles) and Capri (black circles). The black stars indicate the location of Ottenby and Capri. The sample from Capri also includes recoveries of birds ringed or recovered elsewhere in the Campania region (from Scebba 1993).

Aterfyndskarta för grå flugsnappare Muscicapa striata som ringmärkts eller kontrollerats vid Ottenby (grå cirklar) eller Capri (svarta cirklar). De svarta stjärnorna anger Ottenbys och Capris geografiska läge. Caprimaterialet inkluderar återfynd från hela Campania regionen (från Scebba 1993).

Figure 2. Map showing the recoveries of Icterine Warblers Hippolais icterina ringed or controlled at Ottenby (grey circles) and Capri (black circles). The black stars indicate the location of Ottenby and Capri. The sample from Capri also includes recoveries of birds ringed or recovered elsewhere in the Campania region (from Scebba 1993).

Aterfyndskarta för Härmsångare Hippolais icterina som ringmärkts eller kontrollerats vid Ottenby (grå cirklar) eller Capri (svarta cirklar). De svarta stjärnorna anger Ottenbys och Capris geografiska läge. Caprimaterialet inkluderar återfynd från hela Campania regionen (från Scebba 1993). 
Figure 3. Map showing the recoveries of Garden Warblers Sylvia borin ringed or controlled at Ottenby (grey circles) and Capri (black circles). The black stars indicate the location of Ottenby and Capri. The sample from $\mathrm{Ca}$ pri also includes recoveries of birds ringed or recovered elsewhere in the Campania region (from Scebba 1993).

Aterfyndskarta för Trädgårdssångare Sylvia borin som ringmärkts eller kontrollerats vid Ottenby (grå cirklar) eller Capri (svarta cirklar). De svarta stjärnorna anger Ottenbys och Capris geografiska läge. Caprimaterialet inkluderar återfynd från hela Campania regionen (från Scebba 1993).

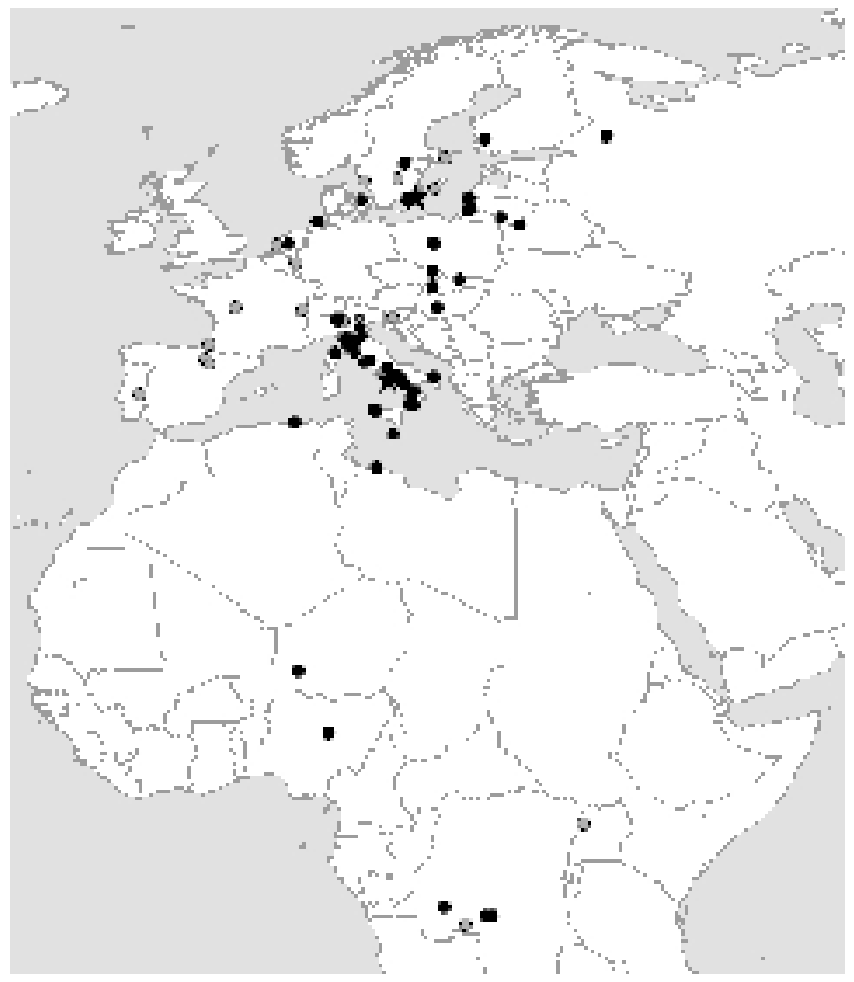

\section{Results}

The ringing recoveries indicate that Spotted Flycatchers and Icterine Warblers (Figures 1 and 2) passing Capri follow a central flyway in Europe and Africa, and are later found in the general direction of Ottenby. A similar pattern was also found for Redstarts, Willow Warblers, Common Whitethroats and Pied Flycatchers (not shown). On the other hand, the recoveries of Garden Warblers suggest a more eastern origin of the birds trapped at Capri compared with those trapped at Ottenby (Figure 3).

Figure 4 shows the linear relationship between median arrival dates on Capri and at Ottenby for each species. The point estimate of the slope was $0.87\left(\mathrm{t}_{5}=8.45, \mathrm{P}<0.001\right)$, which is not significantly different from one $(95 \%$ confidence interval: $0.61-1.14)$. On average, the seven species migrated 15 days ( $0.79 \mathrm{SE})$ later at Ottenby compared to Capri. In order to see if migration speed varied over the season we tested if there was a relationship between species-specific arrival dates on Capri and the differences in median ar- rival dates between Capri and Ottenby. There was a non-significant negative correlation between the species-specific arrival dates on Capri and the differences in median arrival dates between Capri and Ottenby $(\mathrm{r}=-0.57, \mathrm{P}=0.18$; Figure 5$)$.

\section{Discussion}

The strong and positive relationship between migration dates at Ottenby and on Capri suggests that there are either common underlying environmental factors affecting long-distance migrants along their migration route, or that arrival dates are mainly reflecting a specific endogenous time-programme. In long-distance migrants, the onset of migration is known to be under strong endogenous control (Berthold 1996, Gwinner 1996), although the speed of migration through Europe can be affected by local conditions en route, as recently shown in the Pied Flycatcher (Both et al. 2005).

The difference in median arrival date on Capri and at Ottenby may indicate variation in migration speed between species. We find that the Willow Warbler, being the earliest migrant of the species 


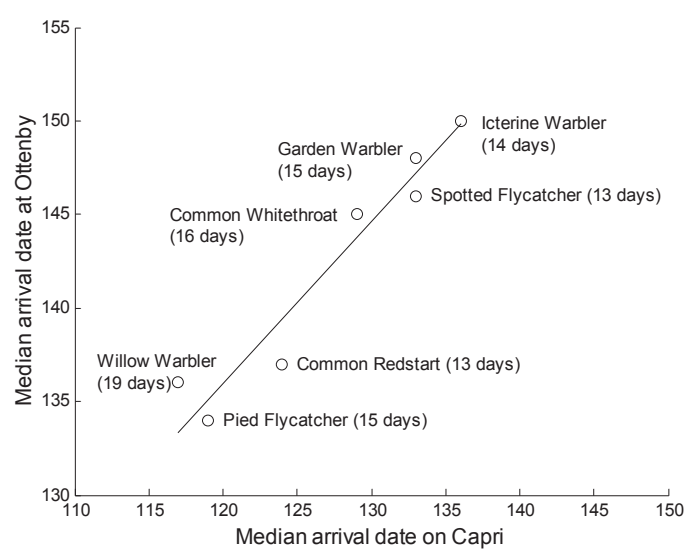

Figure 4. The relationship between median arrival dates on Capri and at Ottenby for seven trans-Sahara migrants, as well as the difference (in days). The line is the estimated slope in a reduced major axis regression (RMA).

Förhållandet mellan mediandatum för vårfångst av sju trans-Saharaflyttare på Capri och vid Ottenby, liksom skillnaden i antal dagar. Den heldragna linjen är den skattade regressionslinjen i en $R M A$ regression.

analysed, is also the species having the largest difference (19 days) in median arrival dates between the two sites. In the same vein, late migrating species such as the Spotted Flycatcher and the Icterine Warbler show a difference of only 13 and 14 days, respectively. However, the overall pattern is weak even though some of the extremes are behaving as expected. It would be interesting to know to what extent the migration speed is limited by the time needed to stop-over. A number of recent studies (e.g. Saino et al. 2004, Both et al. 2005) have shown that arrival time is affected by environmental conditions en route, such that migration speed increases when conditions en route are favourable. If this is a general pattern the timing of migration may not constrain adaptations to climate change as much as previously thought (e.g. Both \& Visser 2001, Both et al. 2005).

Competition for territories is an important factor affecting the timing of migration (Kokko 1999). A close look at Figure 4 shows that all species falling below the regression line (i.e., migrating faster than predicted by the linear model) are using cavities as nesting sites. If cavities are limited one may expect severe competition for territories. In fact, comparative evidence indicates that, among trans-Saharan migrants, hole-nesting species migrate earlier than other species in the Mediterranean (Rubolini et al. 2005). However, to

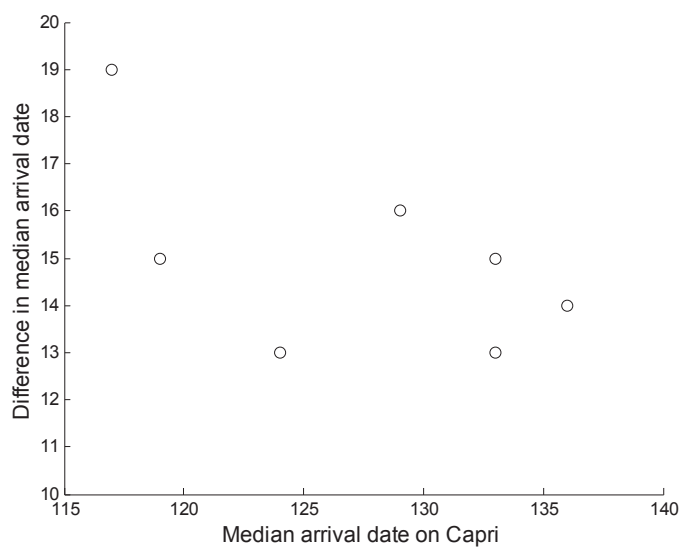

Figure 5. The differences in median arrival dates between Ottenby and Capri plotted against the species-specific arrival dates on Capri. $\mathrm{r}=-0.57, \mathrm{P}=0.18$

Skillnad $i$ medianankomst mellan Ottenby och Capri vid olika (artspecifik) medianankomst på Capri. $r=-0.57, P$ $=0.18$

what extent different species are able to speed up their migration to benefit from the advancement of spring events is currently unknown.

\section{Acknowledgements}

This article is based on the efforts of many Swedish and Italian ringers that have contributed to the running of the long-term trapping series at Ottenby and Capri. Although many people have been involved on Capri, we would like to extend our special gratitude to Carl Edelstam - the founder of the station - and Jan Pettersson. We would also like to thank the present and former staff of Villa San Michele who has contributed significantly to the study of bird migration on Monte Barbarossa - thereby following the intentions of Axel Munthe. N.J. is financially supported by the Swedish Research Council. Finally, we would like to thank Christian Hjort, Dennis Hasselquist and an anonymous referee for constructive comments on an earlier draft of this article. This is contribution no. 208 from Ottenby Bird Observatory, and results from the Progetto Piccole Isole (I.N.F.S.): paper no. 36 .

\section{References}

Beebee, T. J. C. 1995. Amphibian breeding and climate. Nature 374: 219-220. 
Berthold, P. 1996. Control of bird migration. Cambridge University Press. Cambridge.

Both, C. \& Visser, M. E. 2001. Adjustment to climate change is constrained by arrival date in a long-distance migrant bird. Nature 411: 296-298.

Both, C., Bijlsma, R. G. \& Visser, M. E. 2005. Climatic effects on spring migration and breeding in a long-distance migrant, the pied flycatcher Ficedula hypoleuca. Journal of Avian Biology 36: 368-373.

Crick, H. Q. P., Dudley, C., Glue, D. E. \& Thomson, D. L. 1997. UK birds are laying eggs earlier. Nature 388: 526.

Dunn, P. 2004. Breeding dates and reproductive performance. Advances in Ecological Research 35: 69-87.

Fitter, A. H. \& Fitter, R. S. R. 2002. Rapid changes in flowering time in British plants. Science 296: 1689-1691.

Gordo, O., Brotons, L., Ferrer, X. \& Comas, P. 2005. Do changes in climate patterns in wintering areas affect the timing of the spring arrival of trans-Saharan migrant birds? Global Change Biology 11: 12-21.

Gwinner, E. 1996. Circadian and circannual programmes in avian migration. Journal of Experimental Biology 199: 39-48.

Hjort, C. 2006. Capri Bird Observatory - a brief historical overview. Ornis Svecica 16: 13-19.

Holmgren, N. \& Engström, H. 2006. Stopover behaviour of spring migrating Wood Warblers Phylloscopus sibilatrix on the island of Capri, Italy. Ornis Svecica 16: 34-41.

Hüppop, O. \& Hüppop, K. 2003. North Atlantic Oscillation and timing of spring migration in birds. Proceedings of the Royal Society of London Series B 270: 233-240.

Kokko, H. 1999. Competition for early arrival in migratory birds. Journal of Animal Ecology 68: 940-950.

Lehikoinen, E., Sparks, T.H., and Zalakevicius, M. 2004. Arrival and departure dates. Advances in Ecological Research 35: 1-31.

Parmesan, C. \& Yohe, G. 2003. A globally coherent fingerprint of climate change impacts across natural systems. Nature 421: 37-42.

Peñuelas, J., Filella, I. \& Comas, P. 2002. Changed plant and animal life cycles from 1952 to 2000 in the Mediterranean region. Global Change Biology 8: 531-544.

Pettersson, J., Hjort, C., Gezelius, L. \& Johansson, J. 1990. Spring migration of birds on Capri. Special report, Ottenby Bird Observatory [accessible at http://www.sofnet.org/ofstn/index.html]

Roy, D. B. \& Sparks, T. H. 2000. Phenology of British butterflies and climate change. Global Change Biology 6: 407-416.

Rubolini, D., Spina, F. \& Saino, N. 2005. Correlates of timing of spring migration in birds: a comparative study of trans-Saharan migrants. Biological Journal of the Linnean Society 85: 199-210.

Saino, N., Szép, T., Romano, M., Rubolini, D., Spina, F. \& Møller, A.P. 2004. Ecological conditions during winter predict arrival date at the breeding quarters in a transSaharan migratory bird. Ecology Letters 7: 21-25.

Sanz, J. J., Potti, J., Moreno, J., Merino, S. \& Frías O. 2003. Climate change and fitness components of a migratory bird breeding in the Mediterranean region. Global Change Biology 9: 461-472.

Scebba, S. 1993. Gli Uccelli della Campania (Birds of the Campania region). Edizioni Esselibri, Napoli.
Spina, F., Piacentini, D. \& Montemaggiori, A. 2006. Bird migration across the Mediterranean: ringing activities on Capri within the Progetto Piccole Isole. Ornis Svecica 16: $20-26$.

Stenseth, N. C., Mysterud, A., Ottersen, G., Hurrell, J. W., Chan, K. S. \& Lima, M. 2002. Ecological effects of climate fluctuations. Science 297: 1292-1296.

Stervander, M., Lindström, Å., Jonzén, N. \& Andersson, A. 2005. Timing of spring migration in birds: long-term trends, North Atlantic Oscillation and the significance of different migration routes. Journal of Avian Biology 36: $210-221$.

Walther, G.-R., Post, E., Convey, P., Menzel, A., Parmesan, C., Beebee, T. J. C., Fromentin, J.-M., Hoegh-Guldberg, O. \& Bairlein, F. 2002. Ecological responses to recent climate change. Nature 416: 389-395.

\section{Sammanfattning}

Klimatförändringar har gjort att många organismers fenologi har tidigarelagts i norra Europa. Flera tropikflyttande fågelarter anländer allt tidigare och en förklaring till hur detta är möjligt är att flyttningen genom Europa går allt snabbare då vårtemperaturen ökar. Hur pass mycket olika arter kan öka sin flyttningshastighet är okänt och borde bero på deras "normala" hastighet. I denna artikel jämför vi datum för medianankomst på Capri (Italien) och Ottenby (Sverige) på våren hos sju arter som alla övervintrar söder om Sahara. Ringmärkningsåterfynd visar att några arter (t.ex. grå flugsnappare och härmsångare; Figur 1 resp. Figur 2) passerar Capri längs en central flyttningsväg genom Europa och återfinns senare i riktning mot Ottenby. Återfynd av andra arter ringmärkta på Capri (t.ex. trädgårdssångare; Figur 3) pekar på ett östligare ursprung än Ottenby. I Tabell 1 redovisas fångstperioder och antal fångade fåglar under våren på Capri för de sju arter vilkas ankomsttider analyseras i denna uppsats.

Jämför man medianankomst på Capri och Ottenby (Figur 4) finner man att det är ett linjärt förhållande med en lutning på 0.87 som dock inte skiljer sig statistiskt från 1 . I genomsnitt passerar de sju studerade arterna 15 dagar senare på Ottenby än på Capri. Det finns även en icke-signifikant antydan till att ju senare en art flyttar desto snabbare flyttar den genom Europa, att döma av skillnader i medianankomst på Ottenby och Capri (Figur 5). Det är okänt i vilken utsträckning olika arter skulle kunna öka sin flyttningshastighet för att dra nytta av vårens allt tidigare ankomst i norra Europa. Det är därför viktigt att man studerar vilka egenskaper som gör att en art har (eller saknar) förmågan att anpassa sig till klimatförändringar. 